\title{
Assessing does not mean threatening: The purpose of assessment as a key determinant of girls' and boys' performance in a science class
}

\author{
Carine Souchal', Marie-Christine Toczek', Céline Darnon ',2*, \\ Annique Smeding ${ }^{3}$, Fabrizio Butera ${ }^{3}$ and Delphine Martinot ${ }^{1}$ \\ 'Clermont Université, Université Blaise Pascal, Clermont-Ferrand, France \\ ${ }^{2}$ Institut Universitaire de France, France \\ ${ }^{3}$ Université de Lausanne, Switzerland
}

Background. Is it possible to reach performance equality between boys and girls in a science class? Given the stereotypes targeting their groups in scientific domains, diagnostic contexts generally lower girls' performance and non-diagnostic contexts may harm boys' performance.

Aim. The present study tested the effectiveness of a mastery-oriented assessment, allowing both boys and girls to perform at an optimal level in a science class.

Sample. Participants were 120 boys and 72 girls (all high-school students).

Methods. Participants attended a science lesson while expecting a performance-oriented assessment (i.e., an assessment designed to compare and select students), a mastery-oriented assessment (i.e., an assessment designed to help students in their learning), or no assessment of this lesson.

Results. In the mastery-oriented assessment condition, both boys and girls performed at a similarly high level, whereas the performance-oriented assessment condition reduced girls' performance and the no-assessment condition reduced boys' performance.

Conclusions. One way to increase girls' performance on a science test without harming boys' performance is to present assessment as a tool for improving mastery rather than as a tool for comparing performances.

Is gender equality attainable in scientific classes? According to several surveys, although teenage girls are on the way to fill the gender gap historically observed in mathematics (Else-Quest, Hyde, \& Linn, 2010; for a review), their scores in science and math still average 12 points lower than boys' scores in industrialized countries (OECD, 2011). Recent research indicates that girls underperform boys especially when they are placed in

*Correspondence should be addressed to Céline Darnon, Laboratoire de Psychologie Sociale et Cognitive, Clermont Université, Université Blaise Pascal, 34 Avenue Carnot, 63037 Clermont-Ferrand Cedex, France (email: celine.darnon@ univ-bpclermont.fr). 
situations that activate the negative stereotype about their supposed poor scientific abilities (Appel, Kronberger, \& Aronson, 2011; Huguet \& Régner, 2007). Activation of this negative stereotype is particularly likely when the test is presented as diagnostic of abilities, yet boys - unlike girls - benefit more in terms of performance from diagnostic tests than from non-diagnostic ones (Walton \& Cohen, 2003). The reversed effect of test diagnosticity for girls and boys poses a real dilemma in educational contexts, given that assessment - that is, situations involving tests that are used precisely because they are diagnostic of students' abilities - is a pervasive, structurally embedded educational practice and a necessary step for learning.

Is there a solution to this dilemma? Is it possible to use assessment at school in a way that harms neither of the gender groups? In the present paper, we argue that this possibility exists and, more specifically, that the threatening component of assessment for girls resides in the fact that assessment is mainly used as a tool for selection that emphasizes performance goals (i.e., desire to outperform others). If assessment is instead presented as a tool for education that focuses on mastery, learning-oriented goals (i.e., desire to improve one's own level of mastery of the task), the gender gap in scientific disciplines should be lowered.

\section{Diagnosticity and boys' and girls' performance in science}

The stereotype of girls as poor scientific performers has been the object of a great deal of research in psychology (Eccles et al., 1983; Hyde, Fennema, Ryan, Frost, \& Hopp, 1990). Research on stereotype threat (Spencer, Steele, \& Quinn, 1999; see Schmader, Johns, \& Forbes, 2008; Schmader \& Croft, 2011; for reviews) has shown that, when placed in a situation where they may confirm the negative stereotype about their gender group, female students may experience a psychological discomfort that results in a performance decrement. The stereotype threat effect has been examined in a wide range of science-related domains such as math performance (Ambady, Shih, Kim, \& Pittinsky, 2001; Brown \& Josephs, 1999; Quinn \& Spencer, 2001), computer sciences, and engineering (Appel et al., 2011; Bell, Spencer, Iserman, \& Logel, 2003; Smith, Morgan, \& White, 2005; Smith, Sansone, \& White, 2007). Huguet and Régner (2007) as well as Keller and Dauenheimer (2003) have shown that the stereotype threat effect could also appear in schoolchildren. Because abilities in science are precisely those believed to be lower for girls, stereotype threat can appear when a test is merely presented as diagnostic of these abilities (e.g., Bell et al., 2003; Gonzales, Blanton, \& Williams, 2002; Huguet \& Régner, 2007; Spencer et al., 1999, Study 3). In other words, stereotype threat effects can be observed even in the absence of explicit stereotype-activating cues; test diagnosticity alone is sufficient to elicit stereotype threat among female participants, and accordingly, the difficulty is to remove threat from testing situations, not to create it (e.g., Inzlicht \& Kang, 2010).

The issue of test diagnosticity and its negative consequences for girls in scientific domains represents the first side of the assessment dilemma coin. Indeed, at school, assessment is used precisely because it is diagnostic of what students are able to do at a given moment. Given the negative consequences of test diagnosticity for girls, it may be tempting to question the very use of assessment in school and recommend eradicating assessment practices from educational structures to reduce gender inequalities in the classroom. However, would this solution benefit all students?

Several lines of research indicate that assessment is not only an institutional practice aimed at carrying out orientation choices and selection, but also a tool that takes part in 
and supports the process of learning (Black \& Wiliam, 1998; Gibbs \& Simpson, 2004; Hattie \& Timperley, 2007). Research also suggests that, if girls suffer from diagnostic evaluative contexts in scientific domains, boys benefit from such contexts (e.g., Bell et al., 2003; Huguet \& Régner, 2007; Seibt \& Förster, 2004). Indeed, the 'stereotype lift' effect (Walton \& Cohen, 2003) indicates that boys perform better on a test when it is presented as diagnostic of their ability compared to when it is not (i.e., control or low-threat group; see also Walton \& Spencer, 2009). This stereotype lift effect occurs because men benefit, in the diagnostic condition, from positive stereotypic expectations and therefore from downward social comparison with the devalued group of women. Consequently, it appears that - although removing the diagnostic presentation of a test may enhance girls' performance - it may also represent a suboptimal context for boys' performance. This is the second element of the test diagnosticity dilemma.

Considering the two elements of the dilemma discussed thus far, teachers and policymakers may continue to wonder whether they should or should not use diagnostic assessment in classes. We suggest that this dilemma can be solved by reframing the purpose of assessment.

\section{The purpose of assessment}

We argue that what is threatening for low-status groups (e.g., women) is not assessment per se, but rather the purpose of assessment. Recent research indicates that educational systems have two main functions: to educate pupils and students and to select people namely, to assign, or not, grades and degrees in order to orient people to various positions in the social hierarchy (Darnon, Dompnier, Delmas, Pulfrey, \& Butera, 2009; Darnon, Dompnier, \& Poortvliet, 2012; Dornbusch, Glasgow, \& Lin, 1996; Duru-Bellat, 2009). Interestingly, assessment is a tool that can serve both an educational and a selection function (Bloom, Hastings, \& Madaus, 1971). On the one hand, assessment helps the learner achieve mastery of the task by providing formative and corrective feedback (Black \& Wiliam, 1998). On the other hand, assessment serves as a summative and certificative function in that it helps teachers decide who, among students, deserves a degree and who does not (Brookhart, 2001, 2004; Dornbusch et al., 1996).

At the structural level, the distinction between formative and summative functions of assessment echoes a distinction that has received great attention at the individual level: the distinction between 'mastery' or 'learning' goals (desire to increase one's learning) and 'performance' goals (desire to perform well or not to perform poorly as compared to others; Dweck, 1986). ${ }^{1}$ Research in this area has documented that goals affect the way one reacts to an academic task (for reviews, see Elliot, 2005; Hulleman, Schrager, Bodmann, \& Harackiewicz, 2010), including the reaction to failure (Diener \& Dweck, 1978; Dweck \& Leggett, 1988), intrinsic interest (Rawsthorne \& Elliot, 1999), and conflict regulation (Darnon, Butera, \& Harackiewicz, 2007; Darnon, Muller, Schrager, Pannuzzo, \& Butera, 2006).

According to Ames (1992), the assessment process is one of the most powerful factors for eliciting mastery versus performance goals (see also Brookhart, 1997; Pulfrey, Buchs, \& Butera, 2011). Assessment practices that focus on normative standards increase performance goals, whereas assessment practices that emphasize the importance of progress are likely to

\footnotetext{
${ }^{\prime}$ Goal research also makes a distinction between approach and avoidance goals within mastery and performance goals (Elliot \& McGregor, 200I). Because they are the most relevant regarding our hypotheses, in the present research, we will focus on the approach-oriented goals, namely performance-approach and mastery-approach goals.
} 
enhance mastery goals (Butler, 2006). In the remainder of this article, we will refer to the latter type of assessment as 'mastery-oriented assessment' and contrast it to performance-oriented assessment (i.e., based on normative social comparison between students).

\section{Mastery-oriented assessment and girls' and boys' performance}

As previously mentioned, diagnostic assessments may threaten girls in science disciplines. In the present research, we argue that the reason why assessment impairs girls' performance in science is not diagnosticity per se, but the fact that diagnosticity of assessment is most often used for selection purposes. Negatively stereotyped groups feel vulnerable in a comparative, competitive, selective environment. Interestingly, regarding this contention, research on achievement goals indicates that social comparison concerns depend on the salience of goals (Bounoua et al., in press; Darnon, Dompnier, Gilliéron, \& Butera, 2010). Whereas social comparison threatens self-competence in a performance-goal situation (Jagacinski \& Nicholls, 1987; Ryan \& Pintrich, 1997), it is less the case in a mastery goal context, where others are not perceived as threats but as peers with whom collaboration is likely to occur (Poortvliet \& Darnon, 2010). Moreover, mastery goals favour a focus on information relevant to task solving; meanwhile, performance goals lead individuals to focus on self-thoughts related to one's own competence (Butler, 1992). Interestingly, increased salience of (negative) self-related thoughts (Cadinu, Maass, Rosabianca, \& Kiesner, 2005) and the fear of performing poorly compared to others (Brodish \& Devine, 2009) are some of the mechanisms responsible for stereotype threat effects. This is probably why some authors consider that, by default, stereotype threat situations are similar to performance goals - but not mastery goals - situations (see Kaplan \& Maehr, 2007; Ryan \& Ryan, 2005). In line with this idea, some research suggests that women suffer most from the negative effects of performance goals (e.g., Jagacinski, Kumar, \& Kokkinou, 2008). For boys, performance goals can even have a positive effect on the use of efficient learning strategies (Bouffard, Boisvert, Vezeau, \& Larouche, 1995).

In the present study, a performance-oriented and a mastery-oriented assessment of a science class will be compared to a no-assessment situation. We hypothesize that girls will perform better on a science test in mastery-oriented and no-assessment situations compared to a performance-oriented assessment condition. Meanwhile, as previously discussed, boys will not suffer from a performance-goal situation, although the no-assessment situation should reduce their performance. Moreover, unlike the no-assessment situation, the mastery-oriented assessment implies test diagnosticity, which should allow for a sufficient level of visibility and motivational incentive for boys to perform well on the task. Therefore, we expect boys to perform better in the performance-oriented and the mastery-oriented assessment conditions relative to the no-assessment condition.

\section{Method}

\section{Participants}

One hundred and ninety-three high-school students from nine classes participated in this study during one of their obligatory science class. One participant was removed from the analyses because of an uncommon studentized deleted residual. The remaining participants were 120 boys and 72 girls (mean age $=15.6, S D=0.74$ ). Between 23 and 25 girls and between 39 and 41 boys were randomly assigned to each of the three experimental conditions. 


\section{Procedure}

Classes were divided into two groups of students that corresponded to two of the three conditions (mastery-performance, mastery-no assessment, or performance-no assessment) and taken to two different rooms. Each group was taught by one of the two female experimenters, who introduced themselves as future teachers. They first explained that students would be taught a class on aspirin and then, depending on the condition, that they would take, or not, a test on this class.

In the performance-oriented assessment condition, the instructions were as follows:

At the end of today's lesson, you will take a test. On the basis of this test, you will receive a grade. This test will help us compare your abilities to that of other students in the class. You have to know that this grade will count in your final semester grade.

Right before the assessment, students were reminded of the fact that the purpose of the assessment was to see how they were doing compared to others. In the mastery-oriented assessment condition, the instructions were as follows:

At the end of today's lesson, you will take a test. On the basis of this test, you will receive a grade. This test will help you memorize and understand the lesson well. You will see that, even during the test, you will continue to learn. You have to know that this grade will count in your final semester grade.

Before the assessment, they were reminded of the fact that the purpose of the assessment was to help them in the learning process. Finally, in the no-assessment condition, the instructions were as follows:

At the end of today's lesson, you will have to answer some questions. It is important to note that you will not be evaluated on this lesson. Indeed, you will not take any test about today's session.

Before the assessment, students were told:

Now please answer some questions about today's lesson. I will explain to you why I am interested in your answers to these questions after the whole session. Just keep in mind that, as I told you before, today's lesson will not be evaluated.

The lesson lasted approximately $30 \mathrm{~min}$ and presented a variety of information about aspirin (its history, chemical formula, etc.). The two experimenters were trained to provide the exact same content in the class and spend the same amount of time on each part of the lesson. After the class, the experimenter restated the experimental instructions, and then, all students took a test and answered the manipulation check measures. Students were then thanked, debriefed, and explained that this test would actually not count in their final grade.

\section{Materials}

\section{Manipulation checks}

Participants were asked to report whether they thought they would be evaluated. If they answered 'yes', they were asked the extent to which they thought this evaluation was 
'designed to help you in the learning process', 'designed to help you memorize the content of the class', 'aimed at helping you understand well the class', or 'part of the learning process' $(\alpha=.82 ; M=4.81 ; S D=1.32$; mastery-oriented assessment $)$ or 'designed to measure your competences compared to those of the other pupils', 'designed to identify whether you are better or worse than the other pupils', 'designed to compare you to other pupils', or 'designed to see how you do compared to others' $(\alpha=.90$; $M=3.35 ; S D=1.63$; performance-oriented assessment).

\section{Performance}

The test contained 10 multiple-choice questions related to the lesson. For each question, participants had to choose the correct answer among the three suggested (e.g., Which product must be mixed with acetic anhydride to obtain aspirin? Phenol, soda, or salicylic acid?). Scores could range from 0 to $10(M=8.6 ; S D=1.45)$.

\section{Results}

\section{Manipulation checks}

All participants answered the question of whether they would be evaluated or not according to the experimental instructions they received. The two assessment conditions were further compared. Participants from the mastery-oriented assessment condition more often perceived the assessment to be helpful in the learning process $(M=5.06$; $S D=1.41)$ than participants from the performance-oriented assessment condition $(M=4.56 ; S D=1.16), F(1,121)=4.54, p<.04, \eta^{2}=.04$. Symmetrically, participants from the performance-assessment condition $(M=3.96$; $S D=1.59)$ perceived the assessment to be aimed at comparing students to each other more than participants from the mastery-oriented assessment condition $(M=2.73 ; S D=1.42), \quad F(1,118)=19.89$, $p<.001, \eta^{2}=.14 .^{2}$

\section{Performance}

Regarding performance, we expected a drop for girls in the performance-oriented assessment condition and for boys in the no-assessment condition. To test the model summarizing our predictions, the variance was decomposed into two orthogonal contrasts: one one-degree-of-freedom planned comparison testing the model and the other testing the remaining variance. If the model fits the data, the first contrast should be significant, but not the second (Judd \& McClelland, 1989). The performance-assessment condition for girls and the no-assessment condition for boys were each coded -2 , as a drop of performance was expected for these conditions only. The four remaining conditions were each coded +1 . The contrast testing our predictions is presented in Table 1 . The second contrast tested the remaining effects after the model was removed. Because preliminary analyses revealed an experimenter effect, $F(1,180)=6.18, p<.02$, $\eta^{2}=.04$, indicating that performance was higher with one of the experimenters $(M=8,89, S D=1.4)$ than with the other $(M=8,37, S D=1.47)$, this variable and its interactions with other variables were included in the analyses.

\footnotetext{
${ }^{2}$ Differences in degrees of freedom are due to missing values on this variable.
} 
Table I. Contrast of interest

\begin{tabular}{lccc}
\hline & No assessment & Performance-oriented assessment & Mastery-oriented assessment \\
\hline Girls & 1 & -2 & 1 \\
Boys & -2 & 1 & 1 \\
\hline
\end{tabular}

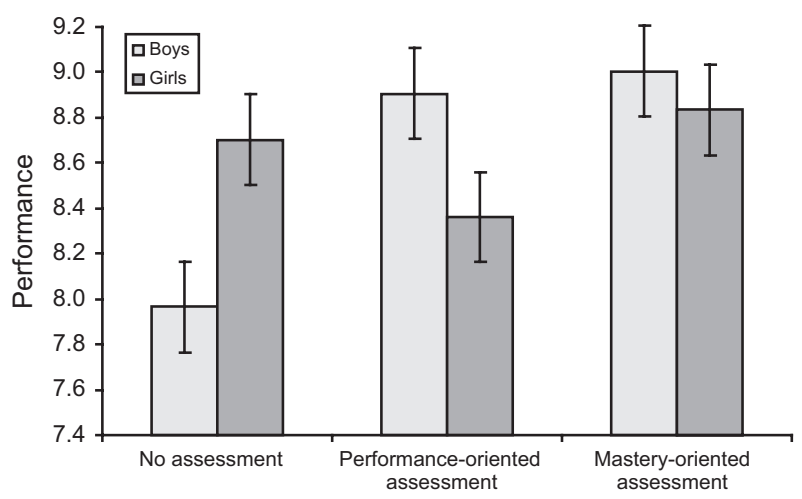

Figure I. Performance at the science test as a function of assessment type and gender.

The 2 (sex) $\times 3$ (assessment condition) $\times 2$ (experimenter) ANOVA indicated that the interaction between condition and sex was significant, $F(2,180)=3.21, p<.05$, $\eta^{2}=.03$. More importantly, the contrast testing the model was significant, $F(1$, $180)=9.40, p<.003, \eta^{2}=.05$, whereas the contrast testing the residual was not, $F$ $(10,180)=1,36, n . s$. Thus, in line with predictions, girls' performance suffered in the performance-oriented assessment condition, whereas boys' performance suffered in the no-assessment situation. The only condition in which both boys and girls performed at their optimal level was the mastery-oriented assessment condition. Means are presented in Figure 1.

\section{Discussion}

Extensive literature has shown that merely presenting a test as diagnostic of scientific abilities is sufficient to observe a gender gap favouring boys' performance (e.g., Bell et al., 2003; Davies, Spencer, Quinn, \& Gerhardstein, 2002; Gonzales et al., 2002). This finding poses a fundamental moral question in terms of assessment practices as they are used in schools. One can indeed argue that one way to reduce inequalities (including gender inequalities) between students could be to remove the assessment process from school. However, this solution is certainly neither optimal nor realistic as assessment is an integral part of the pedagogical process and may be used to promote learning (Brookhart, 1997; Crooks, 1988). Moreover, the stereotype lift effect (Walton \& Cohen, 2003) suggests that no-assessment situations may harm the performance of groups associated with a positive stereotype, such as boys in science, when compared to diagnostic situations.

Is it possible, then, to solve this dilemma and assess students' scientific performance in a way that allows both girls and boys to perform at an optimal level? In the present research, we argued that one way to increase girls' performance on a science test without harming boys' performance is to present assessment as a tool for improving mastery rather 
than as a tool for comparing performances. Our results supported the hypothesis that in the mastery-oriented assessment condition, both boys and girls performed at a similarly high level, whereas the performance-oriented assessment condition reduced girls' performance and the no-assessment condition reduced boys' performance.

The first contribution of the present research is that it provides empirical evidence supporting the hypothesis that assessment in science is threatening for girls, not because it is diagnostic of abilities per se, but because diagnosticity may be used to compare abilities and in fine select students, which is bound to be detrimental to negatively stereotyped group members. Indeed, our results showed that, with a mastery-oriented assessment - a diagnostic assessment - girls performed better than with a performance-oriented assessment and at an equally high level as in the no-assessment condition. The second contribution is that this study demonstrates that there is no need to eliminate assessment altogether to favour girls' performance, which would impair boys' performance. Using assessment as a learning tool provides enough diagnosticity for boys to perform well and eliminates the threatening reference to comparative selection, allowing girls not to underperform.

Some limitations should be noted. First, although stereotype threat and lift effects may explain the results, we manipulated the processes argued to be the origin of both girls' underperformance in science (the comparative and selective aspect of assessment) and boys' (the lack of diagnosticity); but we have no direct evidence that stereotypes were involved. It should be highlighted, however, that according to previous research, test diagnosticity alone is sufficient to elicit stereotype threat (Bell et al., 2003; Gonzales et al., 2002; Huguet \& Régner, 2007; Spencer et al., 1999, Study 3). Moreover, it should be noted that even if we did not have a domain identification measure, science and mathematics - along with French - represent the cornerstone of the academic curriculum in France. Because it has proved difficult to devalue a domain that is highly valued (Crocker \& Major, 1989; Steele, Spencer, \& Aronson, 2002), students should be domain-identified to at least some extent, resulting in threat effects among girls. However, to strengthen our explanation, future research may replicate the present results while manipulating variables directly related to gender stereotypes. A second concern is that, in the present study, students received goal manipulations before the learning phase; thus, it is hard to know whether the threat occurred during learning, during testing, or both (Appel et al., 2011; Rydell, Rydell, \& Boucher, 2010). Future research should examine whether assessment manipulations presented after the learning phase produce similar results. Moreover, goal measures should be included to make sure the assessment inductions resulted not only in different perception of the assessment but also on different goal states. Finally, the present research focused on the approach forms of mastery and performance goals, but future research should also examine the effects of performance-avoidance-oriented assessment. Because performance-avoidance goals are generally associated with threat and anxiety, such a condition should impair both boys' and girls' performance.

Notwithstanding these limitations, the present results have important practical implications. Interestingly, several methods have been proposed to reduce the performance gap between boys and girls in scientific domains. For example, some authors have proposed that promoting self-affirmation (Martens, Johns, Greenberg, \& Schimel, 2006; Miyake et al., 2010), informing participants about the stereotype threat effect (Johns, Schmader, \& Martens, 2005), presenting same gender role models (Marx \& Roman, 2002), or role models who have been successful thanks to regular efforts (Bagès \& Martinot, 2011) could lead girls to perform as well as boys in a scientific domain. These studies are encouraging. However, 
all these interventions consist of helping students cope with the threat; thus, they are all focused on individuals. Classroom practices that generate the threat are rarely questioned. In the current research, we do not document how to individually cope with the threat, but rather how the educational system could change the meaning - and, most importantly, the purpose - attributed to assessment so as not to threaten students. In particular, our research questions the selection function of the educational system and the practices used to exert this function. We believe that, as long as educational institutions have to select and classify people, it will be hard to convince students to focus on the learning of the lessons and not be threatened by diagnostic situations. Therefore, educational institutions should make clear that their role is to educate students and design and use assessment practices accordingly. Only in such a context will students understand that they are in school to learn and not to 'make it through the filter'.

\section{Acknowledgement}

This research was supported by the French Agence Nationale de la Recherche ('Gender Inequality Maintenance') the Conseil régional Auvergne and the Swiss National Science Foundation.

\section{References}

Ambady, N., Shih, M., Kim, A., \& Pittinsky, T. L. (2001). Stereotype susceptibility in children: Effects of identity activation on quantitative performance. Psychological Science, 12, 385-390. doi:10. $1111 / 1467-9280.00371$

Ames, C. (1992). Classrooms: Goals, structures, and student motivation. Journal of Educational Psychology, 84, 261-271. doi:10.1037/0022-0663.84.3.261

Appel, M., Kronberger, N., \& Aronson, J. (2011). Stereotype threat impairs ability building: Effects on test preparation among women in science and technology. European Journal of Social Psychology, 41, 904-913. doi:10.1002/ejsp.835

Bagès, C., \& Martinot, D. (2011). Le rôle de l'explication de la réussite des modèles: qui inspire et qui menace les apprenants? [The role of explaining the success of models: Who inspires and who threatens learners?] In F. Butera, C. Buchs \& C. Darnon (Eds.), Menaces dans l'évaluation (pp. 105-113). Paris, France: Presses Universitaires de France.

Bell, A. E., Spencer, S. J., Iserman, E., \& Logel, C. E. (2003). Stereotype threat and women's performance in engineering. Journal of Engineering Education, 92, 307-312.

Black, P., \& Wiliam, D. (1998). Assessment and classroom learning. Assessment in Education, 5, 771. doi:10.1080/0969595980050102

Bloom, B. S., Hastings, J. T., \& Madaus, G. (1971). Handbook on formative and summative evaluation of student learning. New York, NY: McGraw-Hill.

Bouffard, T., Boisvert, J., Vezeau, C., \& Larouche, C. (1995). The impact of goal orientation on self-regulation and performance among college students. British Journal of Educational Psychology, 65, 317-329. doi:10.1111/j.2044-8279.1995.tb01152.x

Bounoua, L., Cury, F., Régner, I., Huguet, P., Barron, K. E., \& Elliot, A. J. (2012). Motivated use of information about others: Linking the 22 achievement goal model to social comparison propensities and processes. British Journal of Social Psychology, 51, 626-641. doi:10.1111/j. 2044-8309.2011.02027.x

Brodish, A. B., \& Devine, P. G. (2009). The role of performance-avoidance goals and worry in mediating the relationship between stereotype threat and performance. Journal of Experimental Social Psychology, 45, 180-185. doi:10.1016/j.jesp.2008.08.005 
Brookhart, S. M. (1997). A theoretical framework for the role of classroom assessment in motivating student effort and achievement. Applied Measurement in Education, 10, 161-180. doi:10. $1207 / \mathrm{s} 15324818 \mathrm{ame} 1002 \_4$

Brookhart, S. M. (2001). Successful students' formative and summative uses of assessment information. Assessment in Education, 8, 153-169. doi:10.1080/09695940123775

Brookhart, S. M. (2004). Grading. Upper Saddle River, NJ: Pearson Merrill Prentice-Hall.

Brown, R. P., \& Josephs, R. A. (1999). A burden of proof: Stereotype relevance and gender differences in math performance. Journal of Personality and Social Psychology, 76, 246-257. doi: $10.1037 / 0022-3514.76 .2 .246$

Butler, R. (1992). What young people want to know when: Effects of mastery and ability goals on interest in different kinds of social comparisons. Journal of Personality and Social Psychology, 62, 934-943. doi:10.1037/0022-3514.62.6.934

Butler, R. (2006). Are mastery and ability goals both adaptive? Evaluation, initial goal construction and the quality of task engagement. British Journal of Educational Psychology, 76, 595-611. doi:10.1348/000709905X52319

Cadinu, M., Maass, A., Rosabianca, A., \& Kiesner, J. (2005). Why do women underperform under stereotype threat? Psychological Science, 16, 572-578. doi:10.1111/j.0956-7976.2005.01577.x

Crocker, J., \& Major, B. (1989). Social stigma and self-esteem: The self-protective properties of stigma. Psychological Review, 96, 608-630. doi:10.1037/0033-295X.96.4.608

Crooks, T. J. (1988). The impact of classroom evaluation practices on students. Review of Educational Research, 58, 438-481. doi:10.3102/00346543058004438

Darnon, C., Butera, F., \& Harackiewicz, J. M. (2007). Achievement goals in social interactions: Learning with mastery vs. performance goals. Motivation and Emotion, 31, 61-70. doi:10. 1007/s11031-006-9049-2

Darnon, C., Dompnier, B., Delmas, F., Pulfrey, C., \& Butera, F. (2009). Achievement goal promotion at university: Social desirability and social utility of mastery and performance goals. Journal of Personality and Social Psychology, 96, 119-134. doi:10.1037/a0012824

Darnon, C., Dompnier, B., Gilliéron, O., \& Butera, F. (2010). The interplay of mastery and performance goals in social comparison: A multiple goal perspective. Journal of Educational Psychology, 102, 212-222. doi:10.1037/a0018161

Darnon, C., Dompnier, B., \& Poortvliet, M. (2012). Achievement goals in educational contexts: A social psychology perspective. Social and Personality Psychology Compass, 6-10, 760-771. doi:10.1111/j.1751-9004.2012.00457.x

Darnon, C., Muller, D., Schrager, S. M., Pannuzzo, N., \& Butera, F. (2006). Mastery and performance goals predict epistemic and relational conflict regulation. Journal of Educational Psychology, 98, 766-776. doi:10.1037/0022-0663.98.4.766

Davies, P. G., Spencer, S. J., Quinn, D. M., \& Gerhardstein, R. (2002). Consuming images: How television commercials that elicit stereotype threat can restrain women academically and professionally. Personality and Social Psychology Bulletin, 28, 1615-1628. doi:10.1177/ 014616702237644

Diener, C. I., \& Dweck, C. S. (1978). An analysis of learned helplessness: Continuous changes in performance, strategy, and achievement cognitions following failure. Journal of Personality and Social Psychology, 36, 451-462. doi:10.1037/0022-3514.39.5.940

Dornbusch, S. M., Glasgow, K. L., \& Lin, I. (1996). The social structure of schooling. Annual Review of Psychology, 47, 401-429. doi:10.1146/annurev.psych.47.1.401

Duru-Bellat, M. (2009). Le mérite contre la justice. Paris, France: Les Presses de Sciences Po.

Dweck, C. S. (1986). Motivational processes affecting learning. American Psychologist, 41, 10401048. doi:10.1037/0003-066X.41.10.1040

Dweck, C. S., \& Leggett, E. L. (1988). A social-cognitive approach to motivation and personality. Psychological Review, 95, 256-273. doi:10.1037/0033-295X.95.2.256

Eccles, J. E., Adler, T. F., Futterman, R., Goff, S. B., Kaczala, C. M., Meece, J. I., \& Midgley, C. (1983). Expectancies, values, and academic behaviors. In J. T. Spence (Ed.), Achievement and achievement motivation (pp. 75-146). San Francisco, CA: W.H. Freeman. 
Elliot, A. J. (2005). A conceptual history of the achievement goal construct. In A. J. Elliot \& C. Dweck (Eds.), Handbook of competence and motivation (pp. 52-72). New York: The Guilford Press.

Elliot, A. J., \& McGregor, H. A. (2001). A 2*2 achievement goal framework. Journal of Personality and Social Psychology, 80, 501-519. doi:10.1037/0022-3514.80.3.501

Else-Quest, N. M., Hyde, J. S., \& Linn, M. C. (2010). Cross-national patterns of gender differences in mathematics: A meta-analysis. Psychological Bulletin, 136, 103-127. doi:10.1037/a0018053

Gibbs, G., \& Simpson, C. (2004). Conditions under which assessment supports students' learning. Learning and Teaching in Higher Education, 1, 3-31. doi:10.1007/978-3-8348-9837-1

Gonzales, P. M., Blanton, H., \& Williams, K. J. (2002). The effects of stereotype threat and double-minority status on the test performance of Latino women. Personality and Social Psychology Bulletin, 28, 659-670. doi:10.1177/0146167202288010

Hattie, J., \& Timperley, H. (2007). The power of feedback. Review of Educational Research, 77, 81112. doi: $10.3102 / 003465430298487$

Huguet, P., \& Régner, I. (2007). Stereotype threat among schoolgirls in quasiordinary classroom circumstances. Journal of Educational Psychology, 99, 545-560. doi:10.1037/0022-0663.99.3. 545

Hulleman, C. S., Schrager, S. M., Bodmann, S. M., \& Harackiewicz, J. M. (2010). A meta-analytic review of achievement goal measures: Different labels for the same constructs or different constructs with similar labels? Psychological Bulletin, 136, 422-449. doi:10.1037/a0018947

Hyde, J. S., Fennema, E., Ryan, M., Frost, L. A., \& Hopp, C. (1990). Gender comparisons of mathematics attitudes and affect: A meta-analysis. Psychology of Women Quarterly, 14, 299324. doi:10.1111/j.1471-6402.1990.tb00022.x

Inzlicht, M., \& Kang, S. K. (2010). Stereotype threat spillover: How coping with threats to social identity affects aggression, eating, decision making, and attention. Journal of Personality and Social Psychology, 99, 467-481. doi:10.1037/a0018951

Jagacinski, C. M., Kumar, S., \& Kokkinou, I. (2008). Challenge seeking: The relationship of achievement goals to choice of task difficulty level in ego-involving and neutral conditions. Motivation and Emotion, 32, 310-322. doi:10.1007/s11031-008-9103-3

Jagacinski, C. M., \& Nicholls, J. G. (1987). Competence and affect in task involvement and go involvement. The impact of social comparison information. Journal of Educational Psychology, 79, 107-114. doi:10.1037/0022-0663.79.2.107

Johns, M., Schmader, T., \& Martens, A. (2005). Knowing is half the battle: Teaching stereotype threat as a means of improving women's math performance. Psychological Science, 16, 175-179. doi:10.1111/j.0956-7976.2005.00799.x

Judd, C. M., \& McClelland, G. H. (1989). Data analysis: A model comparison approach. San Diego, CA: Harcourt, Brace, Jovanovich.

Kaplan, A., \& Maehr, M. L. (2007). The contribution and prospects of goal orientation theory. Educational Psychology Review, 19, 141-187. doi:10.1007/s10648-006-9012-5

Keller, J., \& Dauenheimer, D. (2003). Stereotype threat in the classroom: Dejection mediates the disrupting threat effect on women's math performance. Personality and Social Psychology Bulletin, 29, 371-381. doi:10.1177/0146167202250218

Martens, A., Johns, M., Greenberg, J., \& Schimel, J. (2006). Combating stereotype threat: The effect of self-affirmation on women's intellectual performance. Journal of Experimental Social Psychology, 42, 236-243. doi:10.1016/j.jesp.2005.04.010

Marx, D. M., \& Roman, J. S. (2002). Female role models: Protecting women's math test performance. Personality and Social Psychology Bulletin, 28, 1183-1193. doi:10.1177/01461672022812004

Miyake, A., Kost-Smith, L., Finkelstein, N., Pollock, S., Cohen, G., \& Ito, T. (2010). Reducing the gender achievement gap in college science: A classroom study of values affirmation. Science, 330, 1234-1237. doi:10.1126/science.1195996

Organisation for Economic Co-operation and Development (OECD) (2011). Education at a Glance 2011: OECD Indicators, OECD Publishing. doi:10.1787/eag-2011-en 
Poortvliet, M., \& Darnon, C. (2010). Towards a more social understanding of achievement goals: The interpersonal effects of mastery and performance goals. Current Directions in Psychological Science, 19, 324-328. doi:10.1177/0963721410383246

Pulfrey, C., Buchs, C., \& Butera, F. (2011). Why grades engender performance-avoidance goals: The mediating role of autonomous motivation. Journal of Educational Psychology, 103, 683-700. doi:10.1037/a0023911

Quinn, D. M., \& Spencer, S. J. (2001). The interference of stereotype threat with women's generation of mathematical problem-solving strategies. Journal of Social Issues, 57, 55-71. doi:10.1111/0022-4537.00201

Rawsthorne, L. J., \& Elliot, A. J. (1999). Achievement goals and intrinsic motivation: A meta-analytic review. Personality and Social Psychology Review, 3, 326-344. doi:10.1207/ s15327957pspr0304_3

Ryan, A. M., \& Pintrich, P. R. (1997). Should I ask for help? The role of motivation and attitudes in adolescents' help seeking in math class. Journal of Educational Psychology, 89, 329-341. doi:10.1037/0022-0663.89.2.329

Ryan, K. E., \& Ryan, A. M. (2005). Psychological processes underlying stereotype threat and standardized math test performance. Educational Psychologist, 40, 53-63. doi:10.1207/ s15326985ep4001_4

Rydell, R. J., Rydell, M. T., \& Boucher, K. L. (2010). The effect of negative performance stereotypes on learning. Journal of Personality and Social Psychology, 99, 883-896. doi:10.1037/ a0021139

Schmader, T., \& Croft, A. (2011). How stereotypes stifle performance potential. Social and Personality Psychology Compass, 5, 792-806. doi:10.1111/j.1751-9004.2011.00390.x

Schmader, T., Johns, M., \& Forbes, C. (2008). An integrated process model of stereotype threat effects on performance. Psychological Review, 115, 336-356. doi:10.1037/0033-295X.115.2. 336

Seibt, B., \& Förster, J. (2004). Stereotype threat and performance: How self-stereotypes influence processing by inducing regulatory foci. Journal of Personality and Social Psychology, 87, 3856. doi:10.1037/0022-3514.87.1.38

Smith, J. L., Morgan, C. L., \& White, P. H. (2005). Investigating a measure of computer technology domain identification: A tool for understanding gender differences and stereotypes. Educational and Psychological Measurement, 65, 336-355. doi:10.1177/0013164404272486

Smith, J. L., Sansone, C., \& White, P. H. (2007). The stereotyped task engagement process: The role of interest and achievement motivation. Journal of Educational Psychology, 99, 99-114. doi:10.1037/0022-0663.99.1.99

Spencer, S. J., Steele, C. M., \& Quinn, D. M. (1999). Stereotype threat and woman's math performance. Journal of Experimental Social Psychology, 35, 4-28. doi:10.1006/jesp.1998. 1373

Steele, C. M., Spencer, S. J., \& Aronson, J. (2002). Contending with group image: The psychology of stereotype and social identity threat. In M. Zanna (Ed.), Advances in experimental social psychology, Vol. 34 (pp. 379-440). New York, NY: Academic Press.

Walton, G. M., \& Cohen, G. L. (2003). Stereotype lift. Journal of Experimental Social Psychology, 39, 456-467. doi:10.1016/S0022-1031(03)00019-2

Walton, G. M., \& Spencer, S. J. (2009). Latent ability: Grades and test scores systematically underestimate the intellectual ability of women and ethnic minority students. Psychological Science, 20, 1132-1139. doi:10.1111/j.1467-9280.2009.02417.x

Received 9 September 20 /2; revised version received 23 January 2013 